\title{
Remarks on semantic peculiarities of numerals and on usage of numerals in several kinds of texts
}

\author{
Larissa Naiditch \\ Institute of Languages, Literature and Art, \\ The Hebrew University of Jerusalem, Mount Scopus, \\ Jerusalem 91905, Israel \\ e-mail: naiditch@h2.hum.huji.ac.il
}

\begin{abstract}
The paper deals with the general peculiarities of numerals. Cases where the sense of numeral cannot simply be explained by the idea of counting, of number, or of order are considered. Special types of texts folklore on the one hand, propaganda on the other hand - are analyzed. For the latter the examples from two Soviet central official newspapers - Pravda and Izvestija of May 1986 have been chosen. These texts partially reflect common stylistic features of Soviet propagandistic discourse of the "period of stagnation"; their specificity is caused by the special situation, which obtained in the country in those days - the catastrophe in the atomic power station in Chernobyl. It is claimed that all the considered examples reflect several aspects of meaning of numerals contained in their general semantics. Thus, the development of the evaluative meaning is explained by the semantics of degree contained in the numerals. These data contribute to Frege's idea of relativity of number, but from another, purely linguistic, point of view.
\end{abstract}

\section{General peculiarities of numerals}

According to a common point of view that seems to be reasonable, numerals are a part of speech or at least a class of words demonstrating a certain grammatical, semantic, and pragmatic unity (Admoni 1968; Melchuk 1985). They form numeral systems in natural languages and are linguistic expressions of numbers. Numerals and numbers are connected with a very important, universal, and ancient human faculty, that of counting. The latter is interrelated with the 
development of the notion of number and of simple arithmetical operations. James R. Hurford, who investigated in his two fundamental monographs different aspects of numerals (Hurford 1975, 1987), considered the cardinality principle, "the disposition to make the sizable inductive leap from a memorized sequence of words to the use of these words expressing the cardinality of collections" (Hurford 1987: 305), an innate capability of man, as the faculty most important for the formation of numerals. Recent studies of numerals in IndoEuropean languages (Gvozdanović 1992; 1999) reveal etymologies and several principles of ordering of Indo-European numeral systems (those based on "five", on "ten", on "twenty", and on "hundred"), contributing to our understanding of these lexical units. As for the origin of numerals, several hypotheses have been proposed, the most popular of these being the referential/pragmatic, the conceptual/verbal, and the ritual. The latter one, also called "eeny, meeny, miny, mo", is that numerals originated from rituals in which "sequences of words which have no referential, propositional, or conceptual meaning are recited while the human actor simultaneously points (in some way) to objects in a collection [...]" (Hurford 1987: 103-104). According to this hypothesis, the connection of numerals with ancient forms of folklore is evident.

Numbers and their linguistic representations, numerals, are based on a kind of abstraction (Frege 1980: 44-51): the objects being counted are considered as uniform, their differences being disregarded. In saying "three apples" we disregard differences of these apples. Objects having nothing in common could be unified because of their number: three apples and three books are similar because of their "threeness". Abstraction, being a general peculiarity of language, manifests itself already in working out a concept and in the nomination of objects. Frege wrote: "If, for example, in considering a white cat and a black, I disregard the properties which serve to distinguish them, then I get presumably the concept "cat"' (Frege 1980: 45). For Frege, numbers are principally different from properties of objects like colours. He writes:

Colour such as blue belongs to a surface independently of any choice of ours. The blue colour is a power of reflecting light of certain wavelength and of absorbing to varying extent lights of other wavelengths; to this, our way of regarding it cannot make the slightest difference. The Number 1 , on the other hand, or 100 or any other Number, cannot be said to belong to the pile of its own right, but at most to belong to it in view of the way in which we have chosen to regard it [...]. (Frege 1980: 29) 
Frege's concept of the subjectivity and the arbitrariness of numbers have been criticized by several philosophers (Resnik 1980: 153-199), especially by Armstrong. They introduced a concept of a single object having, according their point of view, a real basis (Hurford 1987: 132-141). On the other hand, the linguistic relativity of concepts, e.g. this of colours, their dependence on languages, usually referred to as Sapir-Whorf hypothesis, has become a commonplace. In spite of several concepts that seem to show the similarity of numerals to other kinds of words, their specificity is evident. It is not by chance that they show certain closeness to morphological categories. The category of the number also expresses the opposition of one object to many objects. The difference between plural and numeral constructions (e.g. the plural of nouns in Indo-European languages) is that in the plural the quantity is not specified. But this difference is fluid: on the one hand, there exists in several languages dualis denoting two objects; on the other hand, such quantifiers as "several", "many", etc., are similar to numerals (Hurford 1987: 146-158) and may be considered as "unspecified numerals" (Vater 1986: 15; several aspects of interrelations between numerals and quantifiers see also in Reinhart 1997).

Hurford assumed "the semantic representation of any positive whole number $n$ to be $n$ marks on whatever materials medium we can agree to talk about". According to this concept, "the semantic representation of one is /, that of two is //, that of three is ///, and so on ad infinitum" (Hurford 1975: 21; 1987: 142-143). He also considers "the semantics of constructions involving numerals in extensional, or denotational, terms". Whereas "the denotation of cat is the set of all cats, the denotation of red is the set of all red things, [...] the denotation of five cats will be taken to be the set of all collections of cats with just five (cat) numbers" (Hurford 1987: 145). "Cardinal meaning' is that which concerns a class or set of objects and refers to a collection with the corresponding cardinality (in the sentence Those five students the cardinality is "five')" (Hurford 1987: 168). Ordinals refer to cases with "a particular ordered sequence" (Hurford 1987: 170).

In spite of common peculiarities of all numerals, several groups of them are known (Admoni 1968). Besides the common subdivision of them into cardinals and ordinals, there are also additional subgroups: such as collectives (Russ. "dvoe", "troe") (Gvozdanović 1992: 807811), distributives (Russ. "po dva", Germ. "je zwei", French "ils ont dix francs chacun" (Gvozdanović 1992: 142-145, 418-421, 483), multiplicatives (Germ. "dreimal", French "triple") (Gvozdanović 
1992: 93, 328-331, 483-484), proportionals (Germ. "zweifach”, Engl. "twice"), aggregatives (meaning "group of 'n"”) (Gvozdanović 1992: 236), partitives (into 'n' parts) (Gvozdanović 1992: 237). All these subgroups are based on semantic, in most cases also on morphological and syntactical unity and form systems in corresponding languages. Their semantics seems to be simple, cases of polysemy, homonymy, semantic shifts, etc., seem to be excluded.

But let us consider examples usually neglected in the literature about numerals, cases where the sense of numeral cannot simply be explained by the idea of counting, of number, or of order. The examples are given in English, but they are close to universals, showing only slight differences depending on languages: in 1998; she is seventeen; Louis XIV; Fifteenth Street; the Ninth symphony by Beethoven; bus number nine, bus line (route) number nine (in Russian, expressions like "the ninth bus" correspond to the norm of pragmatic usage); one hundred dollars; second grade (it means in English, and in literal translation from Russian as well, a grade of quality of a product: Russian "vtoroj sort" = 'a poor grade, not the best grade'; in American English it concerns also a school grade).

In all of these examples containing cardinals and ordinals, numerals are of course (more or less) connected with the idea of numbers, but only partially. Thus, in such examples as Louis XIV, Catherine II, etc. numbers are parts of names usual for Emperors, for kings, etc. Numbers here could be replaced by other conventional elements, e.g., adjectives and nouns, that are in these special cases synonymous with numerals, e.g., one and the same Russian Tsar is called Peter the First and also Peter the Great (in Russian: 'Pjotr Pervyj' and 'Pjotr Velikij'). The meaning of a place in a sequence typical of ordinals is here not very important; e.g., the fact that Catherine II was preceded by Catherine I is crucial only from the "etymological" point of view. Numerals are used in these names according to tradition and convention, their usage can be explained only on the basis of reasons of designations, by "etymology". In the example of the title of a musical composition, the ninth symphony by Beethoven, the meaning of place in a sequence is probably more salient than in the former examples (the ninth symphony was composed by Beethoven after the eighth), but the conventionality of number is here present as well. Whereas the fact of the sequence-order of composing music by a composer may be crucial for historians of music, for usual hearers the ordinal numeral "ninth" in this context is first of all a title, a name that in this case can be e.g. associated with 
the famous melody or with the choir singing a hymn. I would like to remind the reader of an anecdote that is current in Russia, where the comical effect is based on the ambiguity of the numeral. A man comes to a musical concert later; he asks what is being played. "The ninth symphony by Beethoven", is the answer. "Terrible," says the man, "I came ten minutes later and missed as many as eight". The example with numbers denoting a bus line also demonstrates the conventionality of numeral usage. In making a plan of bus lines in a city it is convenient to designate them by numbers. There is a different tradition for train schedules, probably because the railway traffic is not so regular during long-term periods. Interestingly, there are cases when several regular railway routes and the corresponding trains are designated by special "titles" similar to proper names. Once more, the conventionality of numerals in these cases is used in an anecdote well known in Russia. A man (usually it is Vasilij Ivanovich Chapaev, the famous hero of the Civil War, who became a central person of a series of anecdotes) has to take the bus number 25; he is standing at the bus station and waiting until 24 buses pass. As in the anecdote mentioned above, the humor of this story is based on a pun, on the homonymy of the meaning of numerals. The naive hero (the favorite one in anecdotes) does not understand the conventionality of nomination usual in tradition of Russian language.

These cases only partially correspond to the general meaning of numerals. Let us once more refer to Hurford who wrote: "the denotation of the cardinal numeral five is the set of all collections of five things. [...] the denotation of the ordinal fifth is the set of all objects that are in fifth position in some ordered sequence" (Hurford 1987: 169). The semantics of ordinal as a number or a place in a "contextgiven sequence" as in the example given by Hurford "Ivan was the fifth Ukrainian in the queue" (Hurford 1987: 170) manifests itself in our examples rather in the "etymology" (in reasons for designation) than in the sense itself. The similarity of the cases of numeral usage mentioned above to the proper names consists in the fact that they both do not designate classes of objects having common features. Whereas the common feature of all five objects is their "fiveness", and that of all the fifth objects is their place in the sequence, the fifth or ninth, etc., bus lines in different cities have only their names in common, as in the case of proper names (all men called Peter or Daniel have usually only their names in common). The same could be said of several other examples considered above: the Ninth symphony, Louis XIV. Numbers are here labels. As often in such cases, in spite of 


\section{Larissa Naiditch}

all this, additional associations and sememes can be developed. Inside a certain city, buses (or bus lines) possessing a certain number have common features: their route can evoke a lot of additional connotations, e.g. monuments of architecture, passengers living in a certain neighborhood, other possible individual or collective memories, etc. Thus, the trolley bus number one (in Russian "pervyj trollejbus" 'the first trolley bus') associates in my mind with the central street and the Neva River in St.Petersburg and with the street leading to the University. The symbolism of numbers typical of several cultural traditions also connects numerals with meaning, often in a vague and rather qualificative way, creating oppositions like "lucky — unlucky", "good - bad", etc.

The other examples listed above demonstrate transitional cases (between the usage of numerals described by Hurford and special usage mentioned by us). Thus, a numeral denoting a year is, of course, connected with the notion of sequence, but the development of several additional sememes is possible. Such numerals as 1933, 1937, or 1945 , denote not only an order of a year in a sequence following a conventional term, each succeeding the preceding one, but mean for many speakers something more, evoking complicated associations. The usage of numerals in expressions denoting a sum of money, as in several others, is based on conventional units of measurement accepted in several societies. Nomination of age evokes additional connotations - e.g. the age of seventeen means also 'youth', etc. At the same time, a phone number reflects a pure conventional usage of bare numerals (if several numbers are not connected with the corresponding neighborhood), but can be additionally (individually) associated with a kind of rhythm.

The difference between numerals and other parts of speech (or word classes) can be observed in bilingual speakers or speakers using their second language in everyday life. It is known that people usually count in their mother tongue; but a phone number is, according to my observations, often first remembered in the language of everyday speech (even if it is not the original mother tongue). In any case, the acquisition of foreign language words denoting numbers differs from those of other words, reflecting, as can be supposed, differences of mental representation of these classes of lexemes. On the other hand, the similarity of numeral to several other parts of speech can be traced. As was stated above, numerals in several functions of these are close to other "labels", e.g., personal names (as in a children's poem where kittens were called "One, Two, Three, Four, Five"). 
Being connected with the semantics of a place in a sequence, of quantity, numerals develop additionally the meaning of degree. As noted above, such words as "many", "few", etc. are close to numerals and are included by several scholars in this group of words. The next step in the development of their semantics is the forming of evaluative sememes - one of the universal lexical processes. The trend to the expression of evaluation is an important peculiarity of language, especially salient in adjectives and in some kinds of adverbs. The lexical meaning of the lexeme can be in such cases partially preserved or entirely lost (cf. the history of such words as "very" in English meaning originally "truly'; "sehr" in German, originally 'painful'; "bol'no" 'painful' in Russian that may be used in the meaning 'very', etc.; to mention recent development — "cool" in modern English meaning a high degree of quality). The development of the additional meaning of high quantity and that of high evaluation (as E. M. Volf stated for the case of the adjective: "It could be added: "and this is good" - Volf 1978: 18-20) may be seen in the hyperbolic usage of such words as "millions", "thousands", "hundreds", etc. In these examples, as in several mentioned above, numerals lose the exactness, which is their chief peculiarity. Special kinds of texts are important in this connection.

\section{Numerals in several kinds of texts}

It is evident that numerals are often used in scientific texts, e.g., where statistic data are concerned. The addressees of these texts are specialists possessing the corresponding knowledge and capable of evaluating the information. The latter is very important in the case of numerals because they often have relative values, and their comprehension demands certain presuppositions (including the basic knowledge of other statistic data). But numerals are often met also in texts that are almost opposite to those mentioned above; e.g., in fairytales, epics, and minor forms of folklore (proverbs, riddles). Let me just list a few instances to illustrate the usage of numerals in Russian proverbs:

"U semi njanek ditja bez glazu" — literally: 'the child with seven nurses is in want of control'.

"Sem' raz otmer' — odin raz otrež" — literally: 'measure seven times - cut one time', 
"Odin s soškoj — semero s ložkoj" — literally: 'one with a (wooden) plough — seven with a spoon',

"Sem' bed — odin otvet" — literally 'seven desasters — one answer'.

"Ne imej sto rublej, a imej sto druzej" - literally: 'don't have a hundred roubles, but do have a hundred friends'.

As in all utterances of this kind, proverbs listed above have figurative meaning; they often reflect directive, illocutionary speech acts. Thus, the first one concerns cases when the lack of success is caused by too many persons doing one and the same job, a type of proverb well known in different national traditions (in English: "Too many cooks spoil the broth") and included in the international classification (Kuusi 1972: 699-735, esp. 718; 1978). The directivity of these utterances manifests itself also in the meaning 'many' or 'too many' (evaluation of quantity) that the numerals possess. "Seven" used in these proverbs is a sacred number traditionally common in folklore and representing here "unspecified" numerals; the sense of utterance would not change if "seven" were replaced by another numeral or by "many".

In epics of different national traditions, numerals denoting large quantities ("forty, hundred, thousand") are often used, whereby the same "sacred" numbers ("three, seven, twelve") are found (Toporov 2000). Thus, in one of the Russian epic songs (bylinas) from Novgorod a stone is described as being "thirty ells wide, forty ells long, and three ells high" (Novgorodskie byliny 1978: 105). In another bylina, the sacred book on the origin of the world is described as being "forty spans long, twenty spans wide, and thirty spans thick" (Evgenjeva, Putilov 1958: 272). In the "Nibelungenlied" the stone that Pruenhilde proposed to throw as a part of the competition for her hand is described by several epitheta concerning its dimensions and weight, then it is added that twelve bold and brave heroes could hardly carry it (Aventiure 7, 449 - Brackert 1993: 100). Several examples from the Old Icelandic Elder Edda (in literal prosaic translation): "We have seven chambers full of swords" (Atlaqvitha, 7 - Neckel 1983: 241); "Seven hundred men went to the hall" (Guthrunarqvitha III, 7 Neckel 1983: 233), "We were thirty warriors of birth, eleven of us left alive" (Atlamál Gr. - 51; Neckel 1983: 255). In the majority of examples, numerals in epics are connected with epic heroism; they are used in texts where the strength, great abilities, the power, and the wealth of heroes have to be stressed. Thus, numerals in folklore texts are close to epitheta ornantia. The usage of numerals in proverbs can be connected with the general peculiarities of the latter as a genre of 
folklore and as a type of speech act having directive and figurative rather than direct character. Numerals in epic texts that could in principle be substituted by other ones are partially caused by the peculiarities of this kind of texts, on their formulaic structure based on the principle of "blocks" capable of being substituted in the process of the generation of the text. The "realism" of numerals in these folklore texts is doubtful, in spite of the general possibility of creating corresponding "realistic" images.

Several peculiarities of numerals - those manifesting themselves in folklore texts - cause the possibility of their usage in another genre of texts - in propaganda. Here also formulaic expressions like "millions of people" etc., can be found. The examples to be considered later are taken from two Soviet central official newspapers "Pravda" and "Izvestija" of May 1986. They partially reflect common stylistic features of Soviet propagandistic discourse of the "period of stagnation". Their specificity is caused by the special situation, which obtained in the country in those days - the catastrophe in the atomic power station in Chernobyl. The scale of the catastrophe was clear only to a few people. Journalists were evidently instructed to veil the real tragic events, and they used typical, well-known means to do it. I have chosen these texts to demonstrate the role of numerals in propaganda because the events became a turning point in the consciousness of many people in the Soviet Union. The whole story shows the change of text meaning caused by an extralinguistic situation: propagandistic texts close to mythological ones became suddenly realistic. Besides, in this special case the attitudes of the addressees can be reconstructed, because of the personal experience of the author of this article. The latter is of special importance as the perception of the text by the addressee is the element that is very quickly lost in most cases.

The accident in Chernobyl occurred immediately before the First of May, the official holiday in the USSR. Traditionally, newspapers published then report on the accomplishments of the Soviet people. May 2 the newspaper "Izvestija" wrote:

\footnotetext{
“Segodnja set' avtodorog Tadžikskoj SSR sostavljaet 12728 km. Èto bol'še, čem rasstojanie ot Moskvy do centra Kamčatskoj oblasti." _ "Today the highway network of Tajik SSR accounts for $12728 \mathrm{~km}$. This is more than the distance from Moscow to the center of Kamchatka region'.

"Traktorostroiteli objazalis' v dvenadcatoj pjatiletke dat' 520 tysjač traktorov" — "Tractor constructors committed themselves to producing 520 thousand tractors during the twelfth Five-Year Plan period.'
} 
“Kiev [...]. Zdes' v nynešnem godu vypustjat 285 tysjač mikserov, 60 tysjač kofemolok, 30 tysjač kuchonnych mašin" — 'Kiev [...]. Here 285 thousand mixers, 60 thousand coffee mills, and 30 thousand kitchen units will be produced during this year'.

From the newspaper "Pravda" on the May 1:

"Nefteprochodčiki proburili $10792 \mathrm{~m}$ gornych porod vmesto 10500 po objazatel'stvu" _ ' Miners bored 10792 M of rocks instead of the 10500 they had committed themselves to producing'.

The magic of high numbers was intended to evoke the corresponding sentiments. Because these texts were essentially addressed to readers not specialized in statistics, the numerals were predominantly perceived as decorative and evaluative elements, like signs of heroic deeds in epics. On the other hand, they were known to be a part of texts of a certain genre - of Soviet propagandistic discourse. Many people skilled in reading these texts developed a specific understanding of them. It did not mean that they knew statistics and were interested in the length of highways and the quantities of produced materials, but they rather regarded all these texts as conventional ones. Numerals could be perceived as one of the elements of such texts, having not much in common with real life and even not destined to reflect the reality. It can be said that numerals in these texts, even in cases when they were true, became signs of lying.

The first information on the catastrophe, published in the lower corner of the newspaper's page, was scanty; it did not contain numbers. On May 1 both "Pravda" and "Izvestija" published a short report, where it was mentioned that two persons had died, 197 persons had been brought to hospital, of which 49 had left after medical examination. On the May 2 it was reported that radioactivity on the territory of the Atomic Power Station and in the village had become 1,5-2 times less, and that 18 persons were in a grave condition. At the same time several articles about incidents in power stations abroad appeared. On the May 4 "Pravda" (p. 5) wrote: "As is known, during the period of 1971-1984 in 14 countries of the world 151 accidents took place in the atomic power stations". On the May 6 (p. 4): "Last year ca. 2300 'incidents' were registered in the USA, according to available data". "Izvestija" 5.05: "Accidents on the Atomic Power Stations. USA Washington. 4th of May. (TASS). Nearly 20 thousand different accidents and technical problems occurred in American atomic stations since 1979 [...] In 1979, 2310 incidents occurred in 68 atomic power stations in the USA. [...]In 1980, the number of accidents increased to 3804 , one year later to 4060 . In 1983, there 
were more than 5 thousand". As late as May 8, the first larger article about the events in Chernobyl containing numerical data on the level of radiation appeared. Whereas the journalists continued to use the Soviet political discourse, the perception of these texts by the addressees suddenly changed. The numbers ceased to be mythological ones. Many people consulted the corresponding reference literature and became well informed about the physical parameters connected with the catastrophe, first of all about different levels of radiation and their possible consequences. It was not mythology that they needed, it was realism.

The examples from newspapers listed above demonstrate the usage of numerals in propaganda. As is known, three types of propaganda may be singled out: "the white", "the gray" and the "black" one (O’Donnell, Jowett 1989: 49-63; 1992: 8-19). "White" propaganda is based on "a source which is identified correctly and communicates accurate information", but presented and evaluated in a corresponding manner. "Gray" propaganda is when the source of information is not always correctly identified; it may contain false data. "Black" propaganda is disinformation, containing lies, all types of deceit. Many interesting examples of the usage of statistics to deceive are collected in the book by Darrell Huff (1954) that is a kind of manual for self-defence against lie with numerals. It cannot be excluded that the examples cited above still remain within the bounds of the "white" propaganda or correspond to the "gray" one. As can be seen from the examples listed above, numerals provide substantial aid in compiling propagandistic texts. Their relativity makes the special manipulations possible, which are needed in propaganda. Thus, it could seem that one incident in Chernobyl is not substantial in comparison with 20 thousand accidents in America (here the trick is based on the comparison of things incommensurable in their degrees). Besides, the numerals provide the illusion of exactness and of truth (e.g. the "exact" number 3804 cited above). The connection of numerals with the qualitative semantics and their magic is also important. 


\section{Conclusions}

Our considerations permit us to draw the following conclusions. Special types of texts - folklore on the one hand, propaganda on the other hand - are taken into account.

1. Numerals presuppose a certain generalization and unification of objects, differences being disregarded. Several examples from propagandistic texts mentioned above are based on this peculiarity of numerals. In the sentence "The last year ca. 2300 'incidents' were registered in the USA [...]" the propagandistic trick consists in equating of cases of different degrees. The subtext consists of the possibility of adding to this series another case - that of Chernobyl, to put it into a set of numerous other cases, i.e. to deny its unique character. In formulas like "millions of people" something similar occurs. People are considered as a mass, the differences of personalities being disregarded. As was stated above, generalization is a common peculiarity of language, needed already in forming a notion; grammatical categories also presuppose generalization and unification. In the latter aspect, numerals are, as we have pointed out above, similar to grammatical number, but they are more "marked", they switch attention from the difference of objects to their unity in a set. Leo Weisgerber showed in his classical article "Der Mensch im Akkusativ" the interrelation between several accusative constructions (those with the German transitive verbs like "erfassen", "eingliedern", "einsetzten", "verpflegen", etc.), and the dehumanization, spiritual subordination of the person (Weisgerber 1963). We could state something similar about "the human person in numeral construction".

2. Numerals possess relativity, and this not only in terms of the general arbitrariness of linguistic sign; moreover they depend on scale, on point of view, etc. That is why special knowledge is needed for an evaluation of numerical constructions - the fact that is used in propaganda. Thus, the interpretation of information about the tremendous quantity of produced tractors demands additional background data including other numerals, other kind of knowledge, e.g. if this tractors are needed, where and how they have to be used, etc.

3. Because of the latter, the exactness of numerals is often rather relative. In many texts they provide an illusion of exactness. In "white" and "gray" propaganda numbers help to create the imitation of objectivity. Numbers are also often used in folklore texts (fairytales, epics) that are far from "realism in statistics". The peculiarity of 
these texts consists in the combination of fantastic elements and (pseudo-) exactness. In all these cases of numeral usage the addressee is free to interpret it as a mythological or as a realistic element. Evidently, the specificity of the truth factor is well known here, e.g. in the case of fairytales.

4. Numerals often develop evaluative meaning, because they contain the semantics of degree. Words like "million", "thousand", etc. in singular and plural forms, and other lexemes denoting considerable quantities are often used in a hyperbolic sense and possess the additional sememe of high quantitative evaluation. They provide the impression of monumentality, something that is often used in propaganda tending to monumentalism. Even such a numeral as "seven" (the traditional ritual number) can mean in folklore texts, as was shown above, 'many'. The semantic shift 'great quantity' $>$ 'high evaluation' or at least the connection of numerals denoting high quantity with stylistic "monumentalism" is evident and reflects the general trend to the development of evaluative semantics in languages.

5. The magic of numbers reflecting the ancient belief connected with different sides of life, e.g. with the systematicity of the world picture, manifests itself not only in folklore texts. The traces of such usage of numerals can be observed in several texts, especially those of propaganda containing other features of ritualized texts as well (e.g., epitheta ornantia, epic retardation, repetitions, etc.).

6 . It could be thought that all cases considered above concern the metaphoric usage of numerals. I would like to claim that all these examples reflect one of the aspects of meaning of numerals contained in their general semantics. These data contribute to Frege's idea of relativity of numbers, but from another point of view.

\section{References}

Admoni, V. G. 1968 = Адмони, В. Г. 1968. Полевая природа частей речи (на материале числительных). In: Вопросы теории частей речи. Ленипград: Наука, 98-106. [The field nature of parts of speech].

Brackert, Helmut (ed.) 1993. Das Nibelungenlied: Mittelhochdeutscher Text und Übertragung. Frankfurt am Main: Fischer.

Evgenjeva, А. P.; Putilov, В. N. (eds.) 1958 = Евгеньева, А.П.; Путилов, Б.Н. (eds.) 1958. Древние российские стихотворения собранные Кириею Даниловым. Москва: Издательство Акадкмии Наук. [Russian Ancient Poems Collected by Kirsha Danilov.] 
Frege, Gottlob 1980. The Foundations of Arithmetic. Trans. by J. L. Austin. Evanston: Northwestern University Press.

Gvozdanović, Jadranka (ed.) 1992. Indo-European Numerals. (Trends in Linguistics: Studies and Monographs 57.) Berlin: Mouton de Gruyter.

- (ed.) 1999. Numeral Types and Changes Worldwide. (Trends in Linguistics: Studies and Monographs 118.) Berlin: Mouton de Gruyter.

Huff, Darrell 1954. How to Lie with Statistics. New York: W. W. Norton.

Hurford, James R. 1975. The Linguistic Theory of Numerals. Cambridge: Cambridge University Press.

Hurford, James R. 1987. Language and Number. New York: Basil Blackwell.

Kuusi, Matti 1972. Towards an international type-system of proverbs. Proverbium 19: 699-735.

- 1978 = Кууси, Матти 1978. К вопросу о международной системе пословичньх типов (опьт классификации количественньх пословиц). In: Пермяков, Г. Л. (еd.), Паремиологический сборник. Пословица, загадка. Структура, смысл, текст. Москва: Наука, 53-81.

Melchuk, Igor A. 1985 = Мельчук, И. А. 1985. Поверхностный синтаксис русских числовых выражений. [The surface syntax of Russian numeral expressions]. Wiener slawistischer Almanach, Sonderband 16. Wien.

Neckel, Gustav 1983. Edda: Die Lieder des Codex Regius nebst verwandten Denkmälern Bd. 1. 5. verbesserte Auflage. Heidelberg: Hans Kuhn.

Novgorodskie byliny 1978. Moskva: Nauka. [Bylinas from Novgorod.]

O'Donnell, Victoria; Jowett, Garth S. 1989. Propaganda as a form of communication. In: Smith, Tedd J. III (ed.), Propaganda: A Pluralistic Perspective. Ed. by Tedd J. Smith III. (Media and Society Series.) New York: Praeger, 49-63.

O'Donnell, Victoria; Jowett, Garth S. 1992. Propaganda and Persuasion. Newbury Park: Sage Publications.

Reinhart, Tanya 1997. Quantifier scope: How labor is divided between QR and choice functions. Linguistics and Philosophy 20: 379-397.

Resnik, Michael 1980. Frege and the Philosophy of Mathematics. Ithaca: Cornell University Press.

Toporov, V. N. 2000 = Топоров, В. Н. 2000. Числа. In: Токарев, С. А. (ed.), Мифы народов мира. Энииклопедия. Том 2. Москва: Олимп, 629-631. [Numbers. In: Myths of Peoples of the World. Encyclopedia.]

Vater, Heinz 1986. Zur Abgrenzung der Determinantien und Quantoren. In: Vater, Heinz (ed.). Zur Syntax der Determinantien. (Studien zur deutschen Grammatik.) Tübingen: Narr., 13-31.

Volf, Е. М. 1978 = Вольф, Е. М. 1978. Грамиатика и семантика прилагательного. Москва: Наука. [Grammar and Semantics of the Adjective.]

Weisgerber, Leo 1963. Die vier Stufen der Erforschung der Sprachen. Düsseldorf: Pädagogischer Verlag Schwamm, 215-232. 


\section{О семантических свойствах числительных и об использовании числительных в определенных текстах}

В статье рассматриваются общие свойства числительных как части речи. Особо выделяются те случаи, когда семантика числительного не ограничивается идеей счета, порядка или числа объектов. В связи с этим анализируются примеры использования числительных, с одной стороны, в фольклорных, с другой - в пропагандистских текстах. Так, рассмотрен ряд примеров из газет «Правда» и «Известия» за май 1986 года. Хотя эти тексты типичны для советского политического дискурса, они имеют специфическую особенность: манипуляция числительными должна была скрьть крупнейшгую технологическую катастрофу - аварию на Чернобыльской АЭС. В статье показано, что все случаи использование числительных в текстах отражают их общие частеречные семантические свойства. Так, развитие у числительных оценочной семантики связано со значением степени, входящим в их семантическое поле. Выводы, сделанные автором, соответствуют философской концепции Фреге об относительности цифр и чисел, но касаются лишьь чисто лингвистического аспекта проблемы.

\section{Arvsõnade semantilistest omadustest ja arvsõnade kasutamisest teatud tekstides}

Vaadeldakse arvsõnade kui sõnaliikide üldisi omadusi, pöörates erilist tähelepanu juhtudele, kui arvsõna semantika ei piirdu objektide loendamise, järjestuse või arvu ideega. Sellega seoses analüüsitakse arvsõnade kasutamist (a) folklooritekstides ja (b) propagandistlikes tekstides. On läbi töötatud hulk näiteid 1986. a. mais ilmunud ajalehtedest "Pravda" ja "Izvestija". Kuigi need tekstid on tüüpilised nõukogude poliitilise diskursuse jaoks, on neil siiski ka eripära: arvudega manipuleerimine pidi varjama tõde suurimast tehnoloogilisest katastroofist - avariist Tšernobõli AEJs. Näidatakse, et kõik arvsõnade kasutamise juhud neis tekstides peegeldavad nende üldisi sõnaliigilisi semantilisi omadusi. Näiteks on arvsõnade hinnangulise semantika areng seotud nende tähendusväljas sisalduva järgu tähendusega. Autori poolt tehtud järeldused kattuvad Frege filosoofilise kontseptsiooniga numbrite ja arvude suhtelisusest, kuid siin käsitletakse vaid probleemi lingvistilist aspekti. 